See discussions, stats, and author profiles for this publication at: https://www.researchgate.net/publication/290449914

\title{
Toward a Morphology of Public Space in Suburban Dublin
}

Article in Built Environment · December 2015

DOI: 10.2148/benv.41.4.519

CITATION

READS

1

50

2 authors, including:

Mary P Corcoran

National University of Ireland, Maynooth

45 PUbLiCATIONS 297 CITATIONS

SEE PROFILE

Some of the authors of this publication are also working on these related projects:

Project New Urban Living Project View project 
Mary P. Corcoran, Maynooth University- National University of Ireland, Maynooth and Michael K. Hayes, University College Dublin.

Corresponding author: Mary P. Corcoran, Department of Sociology, Maynooth University, Maynooth, Co. Kildare, IRELAND

Email: mary.corcoran@ nuim.ie, Tel: 0035317083789

Paper submitted for special issue of Built Environment on Suburbia April 21 2015, revised October 192015

Word count 8456 including references 


\begin{abstract}
This paper explores the contemporary commons in suburban space through a sociological and an architectural lens focused on the city of Dublin, Ireland. The green spaces (often left over and oddly shaped) that punctuate contemporary low rise suburban estates in the Dublin suburbs are examined in terms of their role, actual and potential, in generating social and civic life. The paper takes the view that specific architectural interventions have the potential to affect people's perceptions and uses of suburban public spaces. The paper examines (1) the use of green spaces and interstitial spaces by children and (2) the use of allotment gardening spaces by plot holders. The paper argues that while suburban greens and suburban allotments have a "commons" sensibility, that is compromised in practice by the wider political context. Unfettered development, poor design, municipal by-laws and informal social controls on space and its usage result in a symbolic rather than political commons.
\end{abstract}

In this paper we explore and illuminate elements of the interactive order of everyday urban life. We are interested in the potential of green spaces in suburbia to enhance "the commons" at a time when cities are viewed as becoming ever more privatized, more polarized and more exclusionary (Punch 2005, Sennett 2005, Sassen 2013). Following Jacobs (1961), we approach cities as an ongoing work accomplished by those who live, work and socialise in them. In The Death and Life of Great American Cities, Jacobs argued that the nature of the city is best examined through its public realm, sidewalks, parks and neighbourhoods, all of which she viewed as crucial sites of civil encounters. Furthermore, she contended that the well-being and liveability of a city are connected to levels of diversity. Similarly, Sennett has described multi-functionality as the sine qua non for provoking "vivacity in public spaces" (2011, p. 395 and Sennett 1970). Cities that lack a natural and casual public life (one that is serendipitously produced rather than engineered) are more likely to engender social isolation, or as 
Jacobs eloquently observed would "lack public acquaintanceship... and no practice or ease in applying the most ordinary techniques of city public life at lowly levels," ( 1992, p. 65).

Jacobs's somewhat utopian view of the city and its potential has been superseded in recent decades by a more dystopian view that has emphasized the deleterious impacts on cities of such processes as gentrification, privatization, suburbanisation and financialisation. Oldenberg (1989), for instance, highlights the disappearance of informal places in cities- so called "third places" [e.g., local pubs, common land] places that are important for maintaining civil society and democratic engagement. Third places he suggests are being replaced by non-places [e.g.shopping malls, private gyms] where individuals are treated solely as customers and where anonymity prevails.

\section{Place, public realm and commons in suburbia}

Many of the accusations of mono-culturalism and depressed civic life may be aimed at the industrialised scale of mass house-building that emerged in the $20^{\text {th }}$ Century. To some degree this trend was exacerbated by the popularity of a strand of modernist thinking which proposed the application of distinctly zoned functional regions as a means of structuring the contemporary city. While such prerogatives have contributed to the growing proliferation of privatised spaces frequently based upon spending and consumption, the converse is also true.

The metropolis has grown to a multi-nodal region of commercially competing centres. Within this network of points and lines lies suburbia- and it is precisely this dislocation of activities that provides the key to understanding the suburban character. 
Either maligned or ignored its core logic is often disregarded. Yet there is a value in suburbia that remains overlooked.

Plate $1:^{\mathrm{i}}$

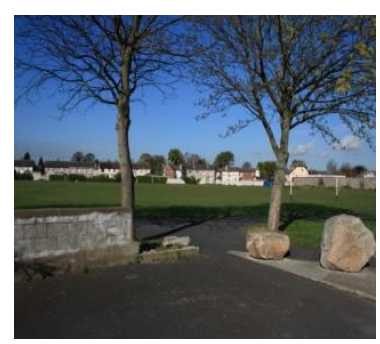

Plate 2:

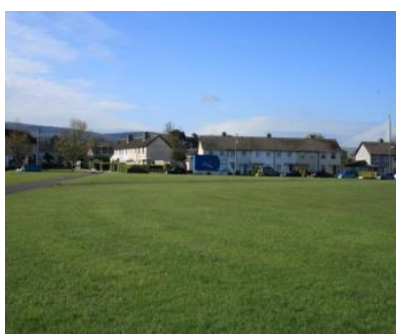

Caption Plates 1 \& 2: green spaces in the inner suburbs, South Dublin.

Distanced from urban centres and avoiding some of the pressures of commerce (via planning policy and construction economics) the former use-value of the old city has migrated with the citizenry to the suburbs. In the oversized or oddly-shaped green spaces there exist opportunities for the civic in suburban life. Free of fences, closing hours, by-laws or even function, these afterthoughts (or precisely because they are afterthoughts) may fulfil the public need for a contemporary commons.

Many of these green spaces incorporate some form of sporting activity, whether formally or informally defined. Such social enactments Ní Mhearáin argues are determined by their set rules, universal dimensions and simple narrative of competition. In doing so, such spaces become the location of a ritualised identity providing a place that gives "citizens a visible status" and that "serve to remind us of our rights and obligations of our history." As such Ní Mhearáin suggests they may be considered a "political landscape". In a similar vein, Eizenberg's (2012) study of community gardens in New York City reveals the possibility of re-envisioning "the commons" outside of a publicprivate dichotomy. Community gardens introduce new social, cultural and political 
practices that make possible alternative frameworks for the management of social relations and social practices.

Plate 3:

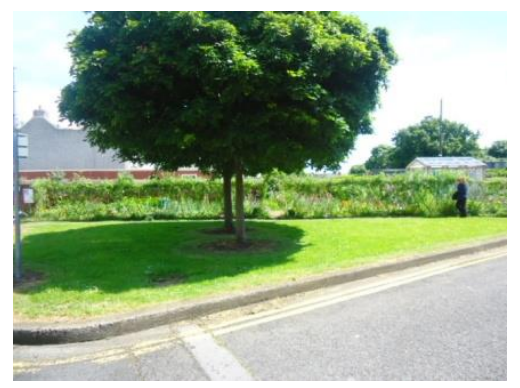

Plate 4:

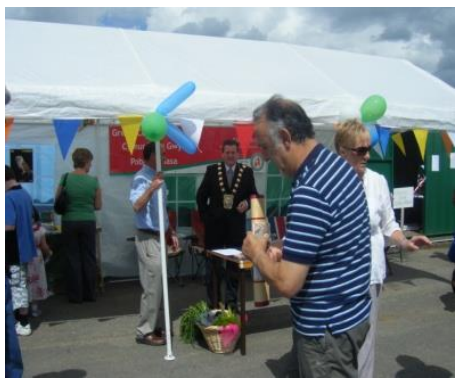

Caption Plate 3: Community Garden, Inner surburb of Phibsboro, Dublin City Caption Plate 4: Allotments Open Day, Friarstown,South County Dublin

As Ní Mhearáin highlights in her research on the relationship between grass and identity in suburbia, a "definition of landscape as a "political" space relates to a wider discourse on the public realm ... set apart from our typical understanding of life in the suburbs.” (2015, no page given) Ní Mhearáin references the work of F.H.A. Aalen (2011), whose writing on Irish rural towns in the $19^{\text {th }}$ century notes the common reliance on market days and fairs as methods of generating a sense of collective place. These transient congregations, gathered under the auspices of an activity and set within a particular context, Aalen describes as a form of ephemeral urbanism:

"where the urbanism is created by congregations of people, engaged with each other in a shared activity, framed in a particular relationship and context, rather than fixed in a defined setting", (Ni Mhearain, 2015 no page given). 
The social life of suburbia then may be partly defined by its temporal nature - a feature rooted in alternative strategies for collective gathering and which distinguishes such spaces from their urban counterparts. It is perhaps also this quality which has prevented extensive external engagement with the suburban environment and led to the conclusion of it being a "placeless" territory devoid of public life. This paper sets out to explore examples of "ephemeral urbanism" in the contemporary Dublin suburbs. To do this we rely on a framework developed by Lownsbrough and Buenderman (2007) who point to the emergence of new types of public space in cities and neighbourhoods: formal and informal, public and semi-public, deliberate or spontaneous. They identify eight main types of "spaces of potential": exchange, production, service provision, activity, democratic/participative, staged, in-between and virtual. These are not to be interpreted in a narrowly spatial sense: in practice many places will have elements that cut across more than one definition, since the category into which a space falls is dictated by the activity happening within it at different times. It is the central importance of trust and confidence from users in creating valuable public space that links these spaces of potential. The elements of new public space include: capacity for multi-use, accessibility, legibility, clarity about the boundaries between public and private, local relevance, adaptability to people's diverse needs and desires, open-endedness and safety.

Plate 5: $\quad$ Plate 6:

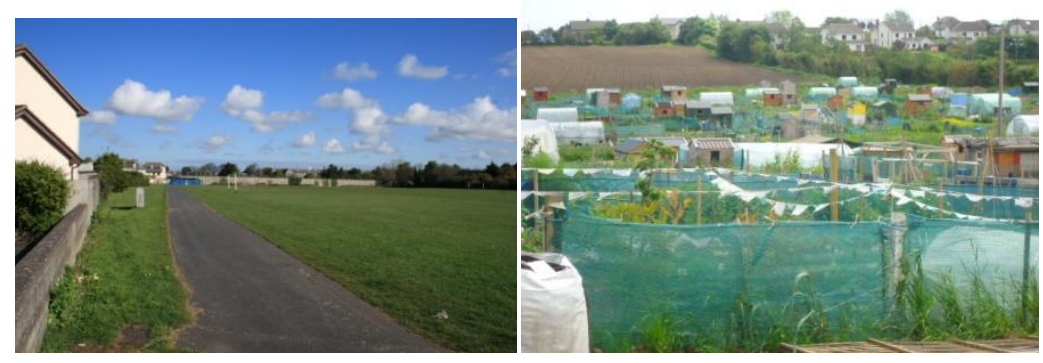


Caption Plate 5: Informal football pitch, South Dublin suburb

Caption Plate 6: Allotment gardens bordering suburban housing, Skerries, Co.Dublin

We take as our point of departure the possibility of moving the analysis of public space beyond questions of inclusion and exclusion, and toward what Madden (2010: 191) calls 'an empirical examination of the powers, practices, institutions, and ideas which do the work of constituting the public" We argue that the empirical investigation of green spaces in suburbia reveals a "commoning" of that space which potentially produces an inclusive and socially cohesive notion of the public. Crucially, though this is a commons that is symbolic rather than political in nature. Developmental, aesthetic, legal and proprietorial considerations- both formal and informal- tend to dictate the conditions under which "the commons" may be accessed, and the kinds of practices that may take place there.

\section{Children, sociability and green space in suburbia}

Suburban neighborhoods have historically relied for their vitality primarily on social ties among the daytime population, generally (though not exclusively) made up of full-time and part-time mothers with young children. It is not surprising that for many suburbanites, the pull of the suburb becomes most appealing precisely at the stage of family formation. Since the world of children is to a large extent confined to the world of 
the neighbourhood, they are important agents in generating and sustaining meeting places. $^{1}$

The analysis that follows is based on a comparative analysis conducted in the early 2000s of four different suburbs at contrasting stages of development, and located at different points in relation to the metropolitan core. Ratoath, Co. Meath, located approximately 30 $\mathrm{km}$ North of Dublin city centre was a very small village until the late 1980s when its population began to multiply dramatically. Ratoath became particularly attractive as a destination for middle class Dublin families seeking to move further out from the city. Leixlip, Co. Kildare, approximately $20 \mathrm{~km}$ west of Dublin city is an established suburb where growth has stabilized. The locus of intense growth in the late 1970s, growth continued at a far slower pace in the 1980s and slowed considerably in the 1990s

The new electoral division of Lucan-Esker, sited to the south of Lucan village in South Dublin county (15 km West from the city centre), grew at a staggering pace in the late 1990s early 2000s, in a locality which was already heavily suburbanised. Finally, Mullingar, an established provincial town in Co. Westmeath $80 \mathrm{~km}$ west of Dublin became a growth pole in the late 1990s attracting commuters squeezed out of the Dublin property market but also enabling many people born and bred in the town to make their homes there.

1 The data presented in this paper is drawn from a major study of the everyday civic and social relations characterising the suburban communities in and around the city of Dublin, Ireland. Four case study suburbs were included: Lucan, Co. Dublin, Leixlip, Co. Kildare, Mullingar, Co. Westmeath and Ratoath, Co. Meath- all at different stages of development and located at different points away from the urban core. The data drawn on here was collected in focus groups with 12 year old school suburban school children. For more details on the study see: Corcoran, M.P., J. Gray and M. Peillon, Suburban Affiliation: social relation in the Greater Dublin Area. Syracuse University Press, 2010. 
Plate 7:

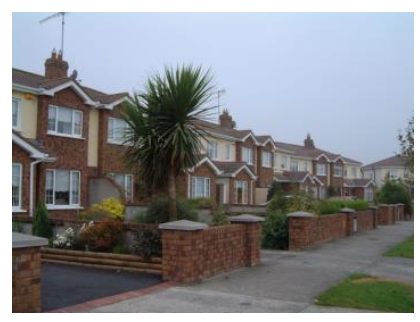

Plate 8:

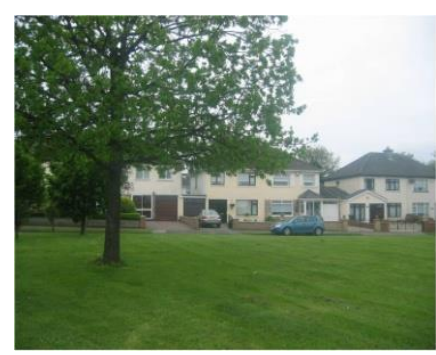

Caption Plate 7 : suburban housing, Ratoath, Co Meath

Caption Plate 8: suburban housing, Leixlip, Co.Kildare

Children across all four localities studied saw their suburban housing estates as their primary arena of sociability after school. Indeed, friendships at school are reinforced through play that continues afterward on the green areas in and around the estates.

In Ratoath, Co. Meath local children singled out green areas in their respective housing estates as being places they enjoyed and utilized for social and recreational purposes. Football (soccer), in particular, was played frequently and there was a general consensus that they would usually have "loads of fun on the green." In Leixlip, Co. Kildare and Mullingar, Co. Westmeath the estate greens are similarly seen as crucial to local quality of life. The ideal estate, according to children in Leixlip, is one that is not too big and is equipped with grass pitches and a nearby shop. One focus-group participant in Mullingar mused on the role of the communal green as an alternative to formal club membership and the confines of a back garden: 
"Unless you have a big garden, and you can play soccer or something, there's not much else to do unless you join a club. Like, there's no fields that you can go to that are set up just for a game of football, if you're not with a club. So you can only do that [play football informally] if you have a big garden." (focus group, St. Colman's National School, Mullingar).

As a group, children in Leixlip tended to congregate on one of the estates or go down to the local village to hang out. Crucially, the estates in Leixlip are within easy reach of the village and local sporting amenities which have developed over several decades. They are in effect walkable for the locals $(1-2 \mathrm{kms})$. The facility to move easily beyond the boundaries of the estate is probably a function of the fact that the area is generally viewed as safe, and access on foot or bicycle to the village and surrounding estates is relatively manageable as the estates border the village so to speak. One housing estate leads through pedestrian walkways into another, and children do not necessarily have to cross any main roads. The physical layout encourages connectedness. The estates we surveyed in Leixlip (and the mature estates located within easy walking distance of Lucan village) most closely emulate the model of Levittown (Gans 1967), where, on reaching school age, children generally walk to the neighborhood primary school and extend the range within which they see friends and school associates by using bicycles (Popenoe 1977, 187). This mobility is significant because research on sustainability and suburban development has demonstrated that lack of pedestrian movement reduces social contacts and slows down processes of community building (Gwilliam et al. 1999, 13).

In contrast, we found that in the newer suburban locations built in the late 1990s and early 2000s in Mullingar (Co. Westmeath) and Ratoath (Co. Meath), freedom of 
movement is somewhat more curtailed largely because of the overwhelming reliance on cars as a mode of transport. In these newer suburban developments, estates are often bisected by busy access roads. In Mullingar, many estates are located on the ring road around the town, and in Ratoath, they developed along traditional country roads on the approach to the village. At the time our research was conducted there was additional traffic and activity associated with continuing development in these localities, giving an unfinished quality to the local environment and creating concerns about "congestion, air quality, noise and public safety on roads" (Gwilliam et al. 1999, 13). Furthermore, development had resulted in the disappearance of different kinds of interstitial "meeting places," leaving children bereft of sociability space. Intensified suburbanization that does not prioritise green space and meeting space has real consequences for the availability of free-play space and for children's overall freedom of movement. ${ }^{2}$

Suburban design has much to offer in terms of fostering children's play networks, as relatively high-density, proximate developments configured around quality green areas, enable local children to widen their pool of potential friends. Variations in estate design means that some estates have green areas that are better suited to communal games such as football and rounders than others. Estates built in the 1970s and 1980s are generally configured in such a way that pedestrian access to congregation points (such as the

${ }^{2}$ Spatially, suburbia is the confluence of horizontal and vertical forces - the result of centuries of evolution from Medieval walled garden to the romantic English landscape style, impinged by the reality of mass housing. Neither the vast expanses afforded by the rural nor the enclosing streetscape of the urban define this context. In suburbia, the dialectic between the astral zenith and vanishing point of the horizon have reached a state of compromise. A balance has been struck so that both exist in equal measure simultaneously. In this way, it could be argued that the historical development of the suburbs has been accompanied by a gradual erosion of the three-dimensional cartesian grid (of the $\mathrm{x}, \mathrm{y}$, and $\mathrm{z}$ axes) in spatial planning, and which has been replaced by the polar co-ordinates of point and line. 
village or local sports amenities) is possible. Green areas are also relatively dispersed. Newer estates, especially those built on the edge of a town or village often feature more intensified housing, configured inward and accessible only by roads.

If the green and the playing pitch act as magnets for sociability, other features of suburban design may act as deterrents to it. Walking and cycling are seriously compromised by high car dependency in suburban neighborhoods. It is also noteworthy that estates that are more or less clearly physically demarcated from each other (by entrance gates, introverted cul-de-sac design, and so on) set symbolic boundaries to the extent of the sociability network in the neighborhood, encouraging intensive rather than extensive circuits of sociability.

The playing of games in suburbia which occurs largely informally on estate greens becomes institutionalized through the playing of GAA (gaelic football and hurling) games on locally provided pitches. One of the unique features of Irish suburbia is the way in which the concept of the local GAA club based historically on the rural parish has managed to successfully reproduce itself in suburban neighbourhoods. For many suburban communities, the local GAA club house and playing pitch are a major focus of weekday and weekend activity involving all the family. As points of assembly on the suburban landscape the playing pitches become an important element of local public space:

"It is these green, flat, seemingly anonymous spaces that can offer an expression of our lives in common and it is grass- with its modest need for tending, its democratic 
uniformity, its softness (for standing, playing and sitting) -that plays host to these lives." (Ni Mhearain, 2015 no page given).

Plate 9

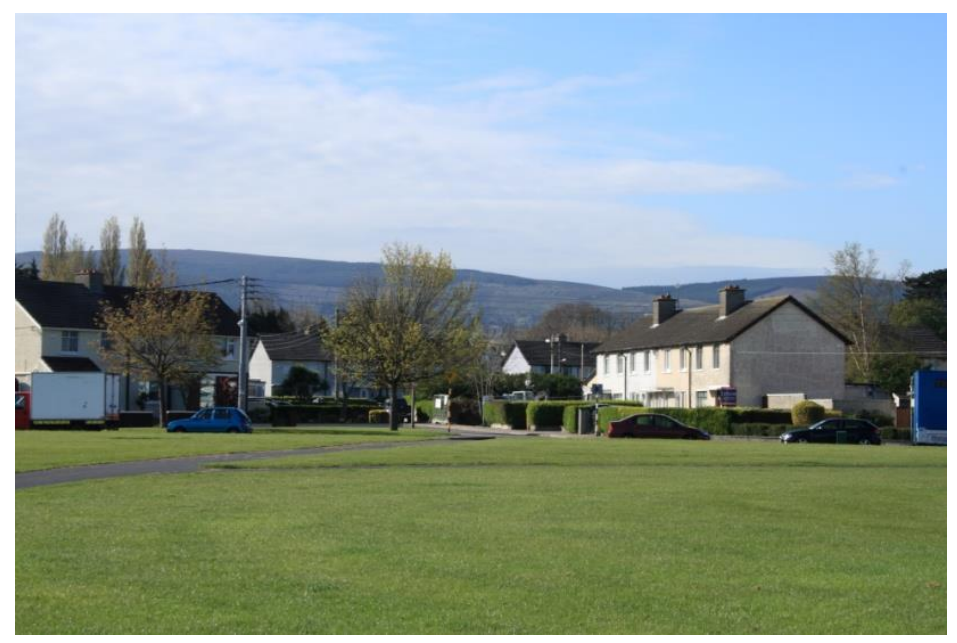

Caption Plate 9: South Dublin suburban green

The availability of public spaces in a given locality is important for several reasons: public spaces enable children's development by providing an arena in which they can interact with other children and form friendships; they act as meeting places and therefore contribute to the social capital stock in a community; and they help to build civility and citizenship because they encourage inclusiveness and co-responsibility (Hart 2006). The presence of a GAA club in a suburban development is a signal of high social capital, and offers a focal point for cross-generational social encounters and the building of local place-based identities. The playing pitches (and the adjacent clubhouse) provide the focal point for encounters that encourage the kinds of local affiliations that enhance civic and social life and that protect against isolation and anomie.

\section{Inhabiting Public Space}


The new "focus on the everyday spaces in and through which children's identities and lives are made and re-made" (Holloway and Valentine 2000, 11) has paid surprisingly little attention to suburban space. We note that children may appropriate open space in the suburbs---such as the interstices between two estates, adjacent fields to new developments, and local park spaces---for their specific use in play or simply hanging out. Only a small number of studies address this aspect of the subject explicitly. Herbert Gans (1967) found that discontent among suburban youth is related to their lack of spaces comparable to agrarian town public spaces. Kevin Lynch's (1997) study of children in a suburban neighborhood in Australia found that children who were denied the opportunity to create their own play space became bored and dissatisfied. Roger Hart (2006) is critical of the provision of formal play areas and playgrounds to the exclusion of lessmanicured, wilder, more flexible landscapes that can provide a creative backdrop for suburban children.

There is, however, a problem of free access to public spaces because of the growing entrapment of children, which is in part fueled by discourses of risk in the wider society, (Bonner 1997). On the one hand, parents seek to minimize risk by ensuring that their children grow up in a safe environment. The desire to raise children in such an environment is a major motivational factor underlying the move to the suburbs. However, if aspects of that environment are deficient (e.g., heavy traffic on the roadways, absence of safe footpaths or cycle paths, and so on), parents continue to worry about their children's safety. On the other hand, children, acting as agents freed (at least temporarily) from parental control, seek to roam the public spaces in and around their neighborhoods 
and to make the neighborhood their own, marking out territory, creating "hanging-out" spots and "arenas for doing nothing."

In Ratoath, children observed that one of the few places left in the locality that they felt they can still call their own is an area referred to as "the Moat," a relatively unused piece of land located at the back of the local church, which they meet up and hang around with friends. In all the focus groups at the local national school, the Moat emerged as a place of importance to local children and was described as "the biggest park we have."

For the most part, children live relatively protected lives, but they do place a premium on having access to spaces for hanging out or doing nothing. "Hanging out" is an important aspect of childhood socialization and often marks a transition to adolescence in children's lives. It provides an important outlet for learning how to develop and sustain social relations away from parental surveillance and it is while interacting with peers that teenagers develop "their own interactional competence, emotional expressions and cognitive constructs...even as they navigate and resist adult authority" (Harrison and Morgan 2005, 94). Hanging out with friends is a favored past-time for children in our study, but their capacity to hang out in or inhabit a public space for the purpose of "doing nothing" is increasingly threatened by changes in the surrounding environment. All of the children expressed dismay at the extent of local development, which they saw as an irritant in several ways. They were critical in particular of noise pollution, the upsurge in traffic, and the disappearance of the green landscape. The impact of development thus manifested itself not only as a physical presence, but as a reminder of what was being lost to them in the locality. In particular, these children are acutely aware of the constraints 
thus placed on their engagement with nature. The "free range kids" movement in North America has raised exactly these concerns arguing for recognition of the interdependence of the health of the environment and of people, and the necessity for neighborhood parks to become more effective natural spaces, (Goltsman et al. 2009).

Children in suburban Ireland perceive their localities to be changing in ways that potentially threaten their freedom of movement and their intimate networks of sociability, making the landscape at once less familiar and much less accessible, as the following observations from children indicate:

Before you could see everywhere, you could see all the grass. Now all you can see around is houses and big buildings. (focus group, Archbishop Ryan National School, Balgaddy, Lucan)

The green is disappearing, they are just building apartments. (focus group, Archbishop Ryan National School, Balgaddy, Lucan)

There's a field near my house where the horses go and where you can play soccer, but now they're building houses behind that. (focus group, St. Colman's National School, Mullingar)

There used to be a forest that we could go to all the time, but now they're actually building on the forest, and when you are near the forest, sometimes you can actually hear them building. (focus group, Ratoath National School, Ratoath) 
The Woodlands used to [have] a field where we could play [but] is gone (developed for housing). The only walk is from the estate to the village along the road because pathways through the fields are gone. (focus group, St. Colman's National School, Mullingar)

Children's freedom to roam the neighborhood is much more curtailed today than it was in the past. Green spaces that are appropriately configured within the design of new housing estates and that are managed well by local residents certainly play a significant part in generating an arena for sociability. However, lost through much of the development are the in-between or liminal "hanging-out" spaces where children can escape from parental control. This loss is regrettable from the children's point of view, but inevitable in developer-driven suburbs. The rural dream that the suburbs hold out for many parents (Bonner 1997) becomes somewhat compromised when the problems associated with the city---such as traffic, noise levels, pollution, and crime---follow them to the new idylls on the city's edge. Although the small, residential suburb with a country feel is preferred, most Irish suburbs (like their American counterparts) have been in transition to large, diverse places in sprawling and increasingly congested regions (Baldassare 1986).

Children in suburban localities essentially operate within residential spheres. More than their parents or other adults in the vicinity, they are confined to their immediate neighborhood. These residential spheres do not necessarily correspond with formal neighborhood boundaries, but rather "are the outcome of a process of mental 
mapping and identification with specific places" (Lupi and Musterd 2006, 814). This mental mapping colors how children perceive the immediate environment of their estates and the proximate environment of the neighborhood in which the estate is embedded. Our research suggests that children growing up in suburban localities develop such mental maps not only through socialization, but also as a result of their own investigation of their residential sphere. They are most at home in their own estate, where feelings of belonging are reinforced through friendship and neighborly networks. Interaction with children from adjacent estates extends their sphere of activity beyond their own immediate estate. Hanging out together and away from parental supervision is possible in public spaces in and around the villages of Ratoath, Lucan, and Leixlip. These public spaces, however, appear to be under threat from continued development, which remains a point of contention for the children.

\section{Public space and the suburban allotment}

The second focus of this paper is on the suburban allotment. Since the economic crash of 2008 in Ireland there has been a demonstrable rise in urban agriculture practices reliant on both public and private provision of allotments in cities and on their perimeter. The rising interest has been partly driven by a flourishing civil society sector committed to promoting sustainable forms of production, greater food awareness, better strategies for health and well-being promotion and the principle of greater food sovereignty. The media has also played an important role reporting on this "ecological turn." Allotment holders now constitute a diverse population. No longer dominated by older, working class males, plots are now tended by working class and middle class women and men, 
immigrants and community groups, and advocacy groups catering for clients with special needs. ${ }^{3}$ Allotment gardening is particularly on the rise in and around the suburban perimeter of Dublin, where demand continues to be greater than supply.

Allotments ${ }^{4}$ are sites of production and exchange which explicitly and typically eschew a cash nexus. Those provided by the municipality (for a relatively modest annual fee) have a strict injunction on the sale of foodstuffs for commercial gain. In that sense they form part of a public green realm, a space between the market and the state, whose functionality derives from cultivation and knowledge exchange. This conceptualization has something in common with Kaul et al.'s (2005) idea of the public good. Public goods are defined as outside the marketplace, the benefits of public goods is that they are marked by non-rivalry in consumption and non excludability. Secondly, their benefits are universal in terms of being accessible to all population groups, and they do not foreclose options for future generations. Furthermore, it is possible to say that publicly provided allotments constitute a merit good as they subsidized by the polity because they are valued by the community. Allotments fulfil the conditions of a public good- in terms of the resource that is offered (publicly or privately provided land), its shared meaning (production and consumption largely outside the market) and behaviour expectations (managing one's own plot diligently benefits all and contributes to the common good).

3 For more see Corcoran and Kettle (2015). Data drawn on in this paper was gathered on allotment sites in and around the city of Dublin between 2009 and 2012.

${ }^{4}$ The 1922 Act which consolidated a number of earlier U.K. Acts codified an allotment garden as an allocation of land 'not exceeding forty poles in extent which is wholly or mainly cultivated by the occupier for the production of vegetable or fruit crops for consumption by himself or his family.' This remains the definition that is used to the present day in both the United Kingdom and Ireland. 
At the same time the spatial distribution of allotments in suburbia raises questions about their accessibility and legibility. While nominally public in terms of location, they exhibit tendencies towards privatization as evident in their weak visibility to the publicat-large, difficulties of access and security concerns. Municipal allotments are provided on public lands, or on private lands leased by the authority. They constitute a resource held in public trust that is potentially open to all. In terms of social practices, however, allotments are at least semi-privatized through gated access, boundary creation and maintenance, and formal tenant/landlord arrangements. They require payment of a fee however nominal which constitutes a further barrier to entry. Some are characterized by contingent status, but all limit security of tenure through an eleven month leasing system. Every year, allotment holders have to re-apply for their sites. Sites that are managed inadequately are not renewed. Furthermore, lengthy waiting lists for allotments indicate that supply exceeds demand and that access is therefore limited for prospective plot holders.

At a very practical level, in terms of their inscription on the suburban landscape, publicly provided allotments have varying degrees of visibility. Allotment sites tend to fall into one of three distinct locational categories: enclosed, interstitial and peripheral. The first two are likely to be found in the inner suburbs, the latter at the edge of the city boundaries close to the outer suburbs. Enclosed allotments spaces are nested within a demarcated space that affords them added privacy, security and surveillance. Examples of these kinds of allotments are walled or gated areas designated within public parks, where there is considerable footfall but the allotments remain almost totally invisible. These enclosed allotments constitute what Lofland (1998) has described as "private bubbles" in 
public space. Nominally, the allotments are on public land, but through the process of enclosure they are rendered out of bounds for the citizenry-at-large. Tymon Park on the South side of Dublin city houses just 13 show-quality allotments behind a walled enclosure adjacent to the home and office of the park ranger. St. Anne's park on the North of the city houses 90 allotments in the existing Victorian-era walled garden originally used by the Guinness family to grow fruit and vegetables. One allotment holder recognized that while the enclosed nature of his allotment diminished its publicness it also enhanced the security of his personal plot. Viewed from the inside out the plot is perceived as a private, protected space:

"[The park authorities] are protecting us with the walls and there is a security thing. That's o.k. I mean if someone had spotted all the peaches on my tree they would be gone!" (MF)

\section{Plate 10}

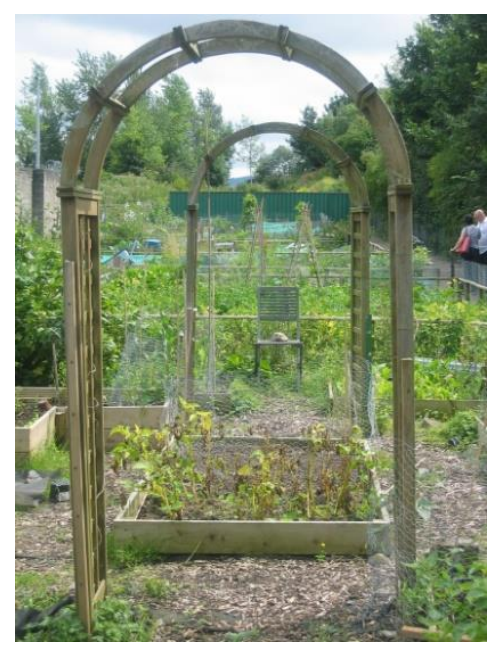

Caption plate 10: Walled allotment garden, Tymon Park, South County Dublin 
While enclosed allotments are sited on public lands- land in theory open to all- they are in reality semi-privatized, secluded and located away from the public gaze. Their existence enables the municipalities to promote their green credentials through an attractive showcase. They can report their support for allotments without having to put their weight behind a bigger and more ambitious project of identifying, negotiating for and developing appropriate sites. Thus, their engagement is more symbolic than substantive in terms of providing commons land for cultivation in the city.

A second type of allotment arises in interstitial spaces, mainly on land that was or is intended for another use. They are defined by their contingent nature and that fact that the plot holders are "place fillers" who may be required to vacate at short notice. Once again, they tend to be well hidden from public view. There is no signage for the Mount Anville allotments in Goatstown, South Dublin. Though located in the middle of a relatively dense mature, suburban development they are extremely hard to find- if you don't know where to look. The land which they occupy has been earmarked for the Eastern bypass, a relief road for traffic in the area. While it is unlikely that the road will ever be completed, there is no long term security of tenure for the allotment holders. They occupy an interstice between a major roadway and a social housing complex that can be decommissioned by the municipality at any time. These allotments can only be approached through a locked gate (pedestrian only entry) on a busy thoroughfare linking south Dublin suburbs to the coastal suburbs. While these allotments occupy a substantial 
tranch of land in a salubrious suburb, as one plot holder observed they have no visibility in the vicinity:

“Oh, it's private space. Yes I think so. It would be nice if they were overlooked if the walls were lower. Mount Anville is particularly private because of the high walls and the gate...people are always peering in and asking 'what's in here, what's going on?"' (CF)

Plate 11:

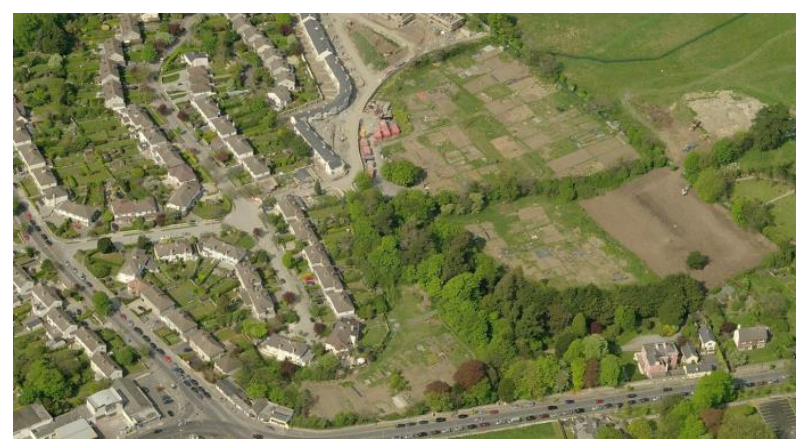

Caption plate 11: allotment gardens in Goatstown, South Dublin

Similarly, the allotments at Palmerstown, on the Western side of the city are secured by an electronic vehicular gate and a padlocked pedestrian gate fronting onto Mill Lane, a rural back road accessible from Palmerstown village. Most of the plot holders ended up here after their previous site in nearby Lucan was cleared for housing development. This site is not owned by South Dublin County Council but is leased from the adjacent Stewart's Hospital, in a land swap deal. It is surrounded on all sides by dense greenery. While this site has not always been gated, it eventually had to be so according to one plot holder because it had become 'a dumping ground'. The susceptibility of public space to 
colonization by undesirable elements is a perennial problem. Public space tends only to work if it is defensible space. The barriers instituted effectively work to keep urban problems- crime, vandalism, rubbish dumping- and the public at bay.

Located in the interstices of the city, these allotments are all but removed from the public eye. They are characterized by transience and contingency. There is always the possibility that they will be requisitioned for other uses. Nevertheless, because they are being used for urban agriculture and are sites of intense productivity they contribute to the green realm in suburbia.

Finally, peripherally located allotment sites are the most recently developed, tend to be larger in overall size, and have been purposively designed by the municipalities as serviced sites. They have been planned and developed directly in response to allotment association and citizen demands for land for cultivation. As one plot holder pointed out these newer, purpose built sites tend to be "more organized, with car parking facilities, pathways between allotments, toilets, public lighting and a locked building for storing tools," (field notes). The city's newest allotments on the North West of the city are located close to a suburban growth pole which expanded dramatically during the Celtic Tiger era, between 1997 and 2007.. Nevertheless, the site is very rural, the approach road is narrow and it is located at some distance (several kilometres) from the nearest housing. It is therefore car dependent.

Plate 12: 


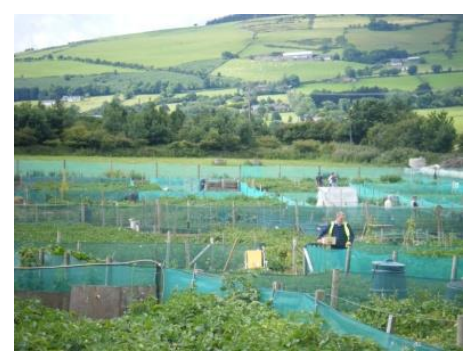

Caption Plate 12: Allotments at Friarstown, South County Dublin

Similarly, Friarstown in Tallaght (South West of the city) is also located at some distance from the nearest conurbation. It is not signposted, but is an impressive site nestling at the foothills of the Dublin mountains and overlooking the city. Peripherally located allotments while more legible in terms of their visible presence in the suburban landscape, are more rationalised in their design and score poorly in terms of accessibility. They are pushing at the city's perimeters, are located at some distance from the nearest housing and are not well served by public transport. Access to the allotment of necessity is dependent on access to a car.

\section{Allotment spaces as arenas of social interaction}

A key feature of these allotment sites is their facilitation of opportunities for social mixing and interaction with unknown others. Allotments provide an arena for individual and collective cultivation, exchange and dissemination of knowledge. They are spaces that are conducive to lingering, and allow plot holders to be individually busy and active, and to interact with one another (which is the opposite of the case in, for instance, an internet café):

"That is the huge potential of allotments, the sense of bringing people together. I really feel that. I have seen that countless times. Out there, there are no 
boundaries or barriers. It is a great social mixing place. Now more people on neighbouring plots might get to know each other because there are no walls or fences like there are with gardens. Every plot almost merges into the next."(MF)

Allotments facilitate the striking up of easy interactions between plot-holders. They are places where strangers seem less strange since because of the shared commitment to cultivation which is predicated on an incipient shared identity:

"When I'm coming for four hours I'll always bring me flask and if someone was around I would say do you want a cup of tea, they might take it and they might not take it." (FN1)

Another plot holder perceives the allotment space as a great leveller, where class and status are bracketed and everyone literally mucks in:

"You're up there in your working clothes. There are no symbols of wealth as such. There are no suits. You know there's no people dressed in their good clobber. You're in there with your spade and your veg and it kind of ...it's a neutralising environment where you wouldn't feel threatened by talking to another person." (FN2). 
Plate 13:

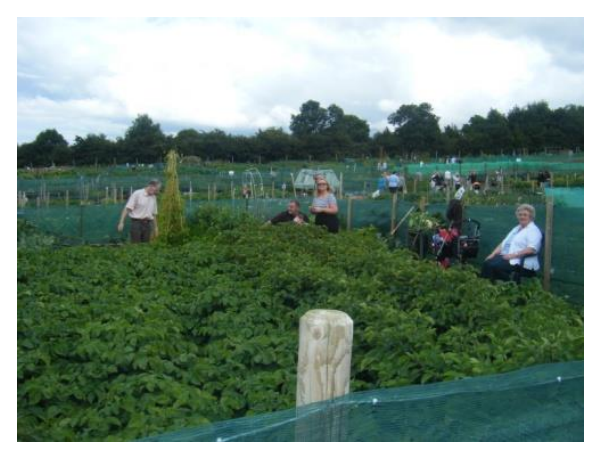

Caption 13: sociality on allotments, Friarstown

Despite the emphasis on sociality, allotments also serve as a refuge from the pressures and demands of everyday suburban life. Ward Thompson has noted that "urban open space must provide a place for the meeting of strangers and a place where one can transcend the crowd and be anonymous or alone" (2002: 70). The allotment plays an important role in providing suburbanites with the opportunity to commune with nature, to interact with unknown others or to simply switch off. As such they are frequently viewed as rural or nature "bubbles" in the suburban domain. Recalling his first allotment in Dublin, one plot holder identified its capacity to be of the city and removed from the city at the same time:

"It was almost rural. You could not hear any passing traffic. On a bright day you could see the city, the industrial landscape. But on a cloudy or foggy day you could imagine that you were in the middle of the country. It was 16 acres of land with pheasant, birds and wildlife." (MF).

Another saw the pleasure in her allotment as an escape from her quotidian world:

“That's my spa, that's my break away. I go in there and because you're locked in as well it feels like you are just away from the whole world. It's brilliant....and 
you're out of the way and nobody can call you in to make a cup of tea or whatever that is." (CN1).

The allotment can simultaneously serve the desire for sociability on the one hand, and the requirement for civil encounters on the other, where those encounters are fleeting and plot holders are left to their own devices. Plot holders move between a sociality based around the management of loose associations with others who share the site, and an individuality which is evident in their work practices and in the way they delineate their allotments through symbolic means producing "bubbles of private space" in the public realm. Each allotment space becomes somewhat privatized within the wider public arena of the site of as a whole. As designated spaces for individual people they afford the opportunity to mark boundaries through gates, posts, nettings, fences and individual plot holders' elaboration of these props. As is the case of suburban residents who counter the homogeneity and uniformity of their estates by aestheticising their homes and beautifying their gardens, plot holders are creative and innovative in inscribing their personal identities on the allotment sites. They create bounded private places within a larger publically provided space.

Plates $14 \& 15$ :
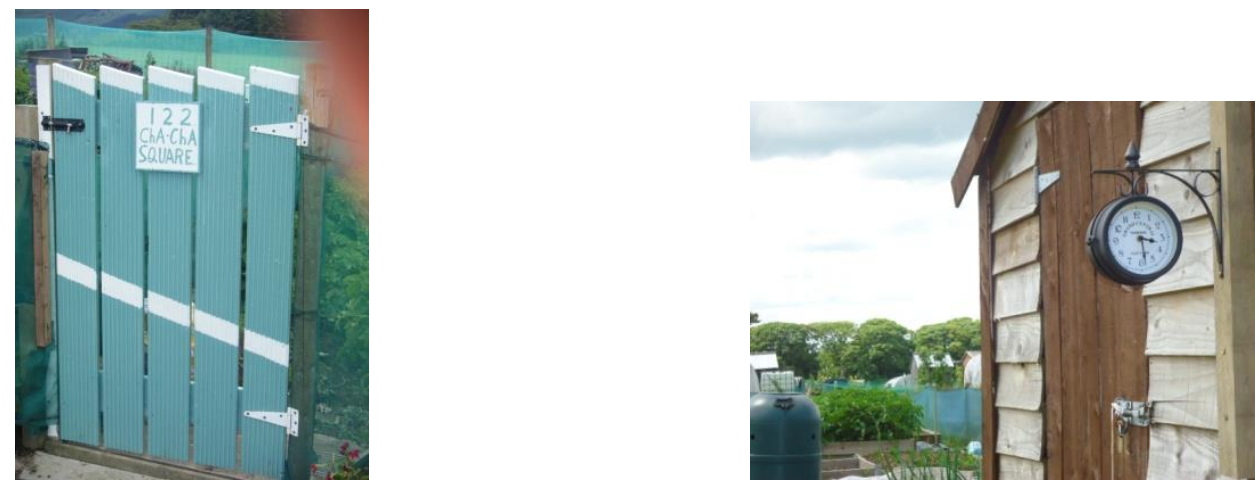
Caption for Plate 14 \& 15: personal identity markers on allotment sites, Fingal allotments, North Dublin

There is an unstated norm that allotment holders engage in low level, informal public surveillance of the site, much as parents do around the common green areas in suburban estates. This ensures a level of safety for the allotment holders (and indeed for suburban children) that one would normally associate with a defended private space. As with the greens in the estates one has to be invited into the space (if one doesn't live there). One had to be permitted or at least vouched for in order to be on an allotment, and behaviour must conform to an (unstated) code of practice which serves as a form of social control:

"There are no physical boundaries on the site once you go in. They are separated by posts with just ropes between the posts, so people can see what other is at. Your line of sight is long, so you can see the whole area. You see people and you get on to nodding or waving terms with people and that would allow for interaction. But there are...you wouldn't dare stray into someone's allotment, borrow a rake without asking, or borrow someone's tools or anything else. And there are also conventions in the sense that the worst thing you can have is a tardy neighbour, with weeds growing, weeds spreading to other areas, there would be a lot of frowning a lot of tut-tutting about that. Your ideal neighbour would be on top of his allotment. There would be a structure to it." (CF) 
Crucially, the behaviour of others in this public space impacts on the enjoyment of each one's own private space. Allotment holders in reality are separated only by permeable boundaries and this denies them absolute control of the space. Seeds and weeds blow in easily from neighbouring plots- your plot is only as good as your neighbour's. Errant neighbours come in for much censure and the municipality's policy is to 'take back' sites that are neglected or abused and reassign them to the next prospective tenant on the list.

\section{Conclusion}

This paper explored the contemporary commons in suburban space through a sociological and architectural lens. The green spaces (often left over and oddly shaped) that punctuate contemporary low rise suburban estates were examined in terms of their role, actual and potential, for generated social and civic life. Specifically, the paper focused on the experiences of children and allotment plot holders in the suburbs of Dublin and their perceptions and uses of suburban public spaces. The paper drew on extensive qualitative data gathered from both groups to demonstrate the centrality of green space to the creation of shared-in-common space in suburbia. We found that public space- often overlooked as marginal or contingent space- is central to this contemporary suburban life world. Ideally, individuals and communities who pass through and use public spaces create and sustain a "commons" where all are welcome, barriers are dismantled, knowledge is exchanged, empathies with others are generated and stereotypes are challenged. For children, creating circuits of sociability around a green area nestled in their suburban housing estates is an important element of personal development and learning how to negotiate the world beyond their home. "Hanging out" 
spaces off the beaten track offer a social space beyond the surveillance gaze of parents. For allotment holders working on the land allows them to develop a cultivation persona which takes primacy over identity markers such as class, gender and ethnicity. The practical activity of land cultivation links users back to the rural past and addresses some of the environmental challenges of the present. Suburban agriculture offers a means to resist the mass consumer model, reconnect people with nature and raise awareness about issues of environment and sustainability. Allotment gardening has the potential to reinvigorate sites that are unused or underutilized to create sustainable models of growth and development, and to foment a green public realm. As such they have a use value and an exchange value for those who work on them. Allotment sites (in contrast to community gardens which are also on the rise in the city of Dublin) cater for both individuality and collectivity. Plots are individualised but the processes and practices involved in managing the plot depend on co-operation and a degree of collective enterprise. Plots are often tended by families, and many plot holders see them as an opportunity to re-connect their own children with nature and develop their environmental awareness.

Estate greens and allotment gardens are aspects of ephemeral urbanism in the contemporary suburban landscape of Dublin. They reveal suburbanites to be both resilient and resourceful as they embrace their public, civic and social selves. Nevertheless, while the greens and the allotments exhibit features of "the commons," they fall short of fulfilling all of the necessary conditions to be deemed "commons" as such. It is more accurate to say that they constitute a symbolic commons or an interstitial public realm. Our analysis reveals tensions and contradictions inherent in the 
"publicness" of these green spaces, objectively and subjectively defined. Strategies of defensiveness work to limit access to public spaces. In practice many allotments are gated and difficult to access. In suburbia open green spaces are being replaced by more manicured green areas within gated communities. Privatisation processes are also at work. While allotments are nominally public in character, like many other seemingly public spaces they have both explicit and implicit barriers to entry that may diminish their 'publicness.' While ostensibly public, the location of allotments largely away from the public gaze engenders a kind of incipient privatisation of the space. Once within the allotment sites themselves, the perceptions of users oscillate between notions of 'publicness' expressed in terms of their public spiritedness and collective orientation and notions of privacy associated with a view of the allotment as a place of personal refuge and retreat. Children in suburbia tend to make the interstitial left-over green areas in and around their suburban estates "hanging out" places only to see those spaces disappear as private landowners turn over the spaces for development. Finally, the discourse of safety ensures that green spaces in suburban estates and allotment gardens are surveilled, monitored and informally policed at all times. They are not the kind of unpoliced "wild spaces" that interrupt the planned landscapes of the suburbs that Hart (2006) advocates. Unfettered development, poor design, municipal by-laws and informal social controls on space and its usage result in a symbolic rather than political commons. 


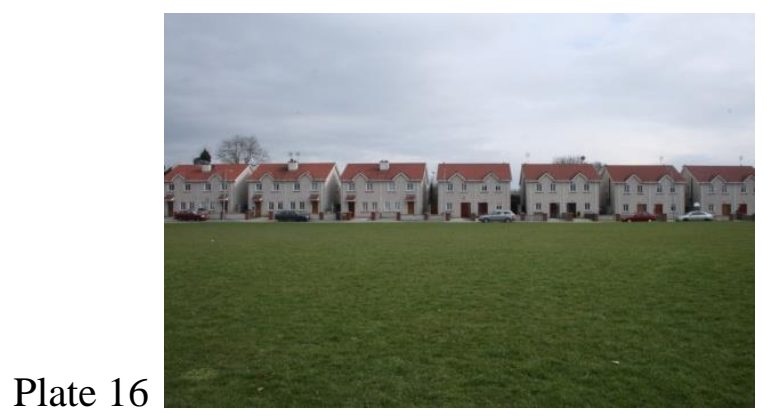

Caption plate 16: Suburban-type housing, Cahir, Co. Tipperary

The planning implications of these findings are clear. Green environments in and around the city are crucial to sense of place and sense of well-being. In developing local area plans, local authorities could be much more creative and pro-active about factoring in green spaces for common usage. Such spaces should be located as close as possible to housing, should be dispersed rather than centralised and should cater for both cultivation and recreation. Effective natural spaces in suburbia must be accessible (on foot or bicycle) thus promoting walkability and freedom of movement, particularly for children. Congregation points must be designed with a variety of potential users in mind. Suburbs need to have designated growing spaces for the urban gardener, but they also need to have places for "doing nothing"- greens that are not manincured and purposeful but natural and open to multi-usage by children and young people. Ephemeral urbanism- a true inhabiting of the commons- is possible where we create and sustain interaction spaces that allow for the congregation of people, engagement with each other in singular and shared activities in a variety of planned, pop-up and interstitial spaces. 


\section{BIBLIOGRAPHY:}

Alaen, F.H.A. K.Whelan, and M.Stout. 2011.(eds).The Atlas of the Irish rural landscape. Cork: Cork University Press

Baldassare, Mark. 1986. Trouble in Paradise.: the suburban transformation in America. New York: Columbia University Press.

Bonner, Kieran. 1997. A Great Place to Raise Kids: Interpretation, Science and the Urban-Rural Divide. Montreal and Kingston: McGill Queen's University Press.

Gans, H. 1967. The Levittowners. New York: Pantheon

Eizenberg, E., 2012. Actually Existing Commons: three Moments of Space of Community Gardens in New York City, Antipode, 43 (3) 764-782

Goltsman, Susan, Laurel Kelly, Susan McKay,Patricia Algara and Larry Wight. 2009.

"Raising 'Free Range Kids': Creating neighbourhood parks that promote environmental stewardship", Journal of Green Building, Vol. 4, No. Spring pps. 90-106

Gwillam, Michael, Caroline Bourne, Corinne Swain, and Anna Prat. 1999. "Sustainable

Renewal of Suburban Areas." Report for the Joseph Rowntree Foundation.

York: YPS in association with JRF.

Harrison, and Morgan. 2005. "Hanging out among Teenagers: resistance, gender and personal relationships" pp. in C. Morrill et al. (eds) Together Alone: personal relationships in public places.

Hart, Roger. 2006. "Children and Public spaces: how adult agendas affect children's well-being" Children's Research Centre Annual Lecture, University of Dublin, Trinity College, October $26^{\text {th }}$.

Holloway, S. L. and G. Valentine. 2000. "Children's Geographies and the new social studies of childhood" pp. 1-26 in Holloway, S.L. and G. Valentine (eds) Children's geographies: playing, living and learning. Routledge: London and New York.

Jacobs, J., [1961] 1992. The Death and Life of Great American Cities, Vintage: New York.

Kaul, Inge. Exploring the policy space between markets and states: global public private partnerships. UNDP, 2005

Lofland, Lyn H. 1998. The public realm: exploring the city's quintessential social territory.

Lownsbrough H. and Beunderman, J., 2007. Equally Spaced? Public space and interaction between diverse communities. London: Demos.

Lupi, Tineke and Sako Musterd "The Suburban 'Community Question' in Urban Studies, Vol 43, No. 4 April 2006 pp.801- 818

Lynch, K. 1997. Growing up in Cities. Cambridge, MA: MIT Press.

Madden, D.,2010. Revisiting the end of public space: assembling the public in an urban park, City and Community, Vol, 9, No.2 June, 187-207

Ní Mhearáin, A. 2015. Greenfields: grass and identity in suburbia. 2Ha Number 9: Suburbia and Leisure, A field of Green.

Oldenburg, R., The Great Good Place, New York: Paragon House, 1989

Popenoe, David. 1977. The Suburban Environment: Sweden and the United States.

Chicago: University of Chicago Press.

Punch, M., 2005. Problem drug use in the political economy of urban restructuring: heroin, class and governance in Dublin, Antipode, Vol. 37, No.4, 754-774 
Sassen, S., 2013. Expulsions: the fifth circle of hell. Public Lecture, Trinity College Dublin, January 13.

Sennett, R., 1970. The uses of disorder: personal identity and city life. New York: Knopf Sennett, R., 2005. Civility Urban Age Bulletin 1, Summer.

Sennett, R., 2011. Reflections on the public realm. In G.Bridge and S. Watson., eds.The

New Blackwell Companion to the City. Somerset, N.J.: John Wiley and Sons, 391-397

Ward Thompson, Catherine. (2002) "Urban Open Space in the Twenty first century" Landscaping and Planning (60) pps. 59-72

${ }^{i}$ All photographs taken by either Mary P. Corcoran or Michael K. Hayes 